\title{
Shotgun Proteomics Identifies Proteins Specific for Acute Renal Transplant Rejection
}

\author{
Tara K. Sigdel $^{1}$, Amit Kaushal ${ }^{2}$, Marina Gritsenko ${ }^{3}$, Angela D. Norbeck ${ }^{3}$, Wei-Jun Qian ${ }^{3}$, \\ Wenzhong Xiao ${ }^{2}$, David G. Camp $\|^{3}$, Richard D. Smith ${ }^{3}$, and Minnie M. Sarwal ${ }^{1}$ \\ ${ }^{1}$ Department of Pediatrics, 300 Pasteur Dr, S378 Grant Bldg, Stanford University School of \\ Medicine, Stanford, CA 94305 \\ 2 Department of Biochemistry, 251 Campus Dr, Stanford University, Stanford, CA 94305 \\ ${ }^{3}$ Battelle, Pacific Northwest National Laboratory, Richland, WA 99352, USA
}

\section{Abstract}

Acute rejection (AR) remains the primary risk factor for renal transplant outcome; development of non-invasive diagnostic biomarkers for AR is an unmet need. We used shotgun proteomics applying LC-MS/MS and ELISA to analyze a set of 92urine samples, from patients with AR, stable grafts (STA), proteinuria (NS), and healthy controls (HC). A total of 1446 urinary proteins were identified along with a number of NS specific, renal transplantation specific and AR specific proteins. Relative abundance of identified urinary proteins was measured by protein-level spectral counts adopting a weighted fold-change statistic, assigning increased weight for more frequently observed proteins. We have identified alterations in a number of specific urinary proteins in AR, primarily relating to MHC antigens, the complement cascade and extra-cellular matrix proteins. A subset of proteins (UMOD, SERPINF1 and CD44), have been further cross-validated by ELISA in an independent set of urine samples, for significant differences in the abundance of these urinary proteins in AR. This label-free, semi-quantitative approach for sampling the urinary proteome in normal and disease states provides a robust and sensitive method for detection of urinary proteins for serial, non-invasive clinical monitoring for graft rejection after kidney transplantation.

\section{Keywords}

Renal transplantation; Acute rejection; Biomarkers; Urinary proteomics; ELISA

\section{Introduction}

Publication of human genome data has facilitated high throughput studies, including the large scale analysis of human proteins in different biofluids[1-2]. Biofluids such as blood, urine, nipple aspirate fluid, bronchoalveolar lavage and cerebrospinal fluid [3-6], have been analyzed by various proteomics techniques, and based on their relevance to the concerned disease; however, detection of low abundance proteins and the identification of the statistically significant proteins are still positioned as bottlenecks for proteomics analysis.

Recent studies [7-11], including those by Adachi et al [12] and Gonzales et al [13] have used gel-based as well as gel-free proteomics approaches to contribute to the atlas of urinary proteins in normal individuals. Using 1-D SDS-PAGE and a reversed phase HPLC protein separation

The name and address for correspondence: Minnie Sarwal, MD, MRCP, DCH, PhD, Stanford University Medical School, G306, 300 Pasteur Drive, Stanford, CA 94304, msarwal@ stanford.edu, Phone: 650723 7903, Fax: 6507234517. 
and fractionation method followed by application of LTQ-FT and LTQ-Orbitrap technology, Adachi et al. analyzed urine samples collected from healthy individuals and identified 1543 proteins [12]. Gonzales et al. analyzed urinary exosomes using LC-MS/MS and identified 1132 proteins [13]. In this study, we have undertaken a pilot study of 10 normal samples, 40 urinary samples from patients with nephrotic syndrome as well as renal transplant patients with stable graft function and biopsy proven AR. The purpose of the study was to study if phenotype specific differences could be identified in urinary samples from patients with different etiologies of native and transplant-associated renal injury.

The benefit of identifying rejection-specific proteome biomarkers in urine is very relevant. Renal transplantation is the ultimate treatment for patients with end stage kidney disease [14], but there is no current non-invasive means to monitor for acute graft rejection. The renal biopsy, the gold standard for diagnosing rejection, is an invasive procedure that suffers from sampling heterogeneity, has associated complications of pain, sedation, hematuria, arteriovenous fistulae, graft thrombosis and transfusion risk [15], and correlates poorly with treatment response and prognosis. Because of the ability of urine to reflect both local processes within the kidney as well as a reflection of changes within plasma, urine is particularly useful to diagnose kidney diseases and kidney transplant dysfunction [16]. Discovery of a urine biomarker for assessing the rejection status of patients following kidney transplant could significantly improve patient outcomes and decrease the cost of care.

To test the validity of the discovery of AR-specific protein biomarkers by our study approach, we performed ELISA assays on selected protein biomarkers using an independent set of 52 unique patient urines. ELISA results established that the approach taken in this study is a viable way to discover potential biomarkers. The report demonstrates how high-throughput, highcost, labor-intensive MS-based discovery can eventually be developed into an economical, rapid turn-around, clinically applicable diagnostic assay for transplant patients.

\section{Materials and Methods}

\section{Materials}

The following reagents were used for the proteomics sample preparation: nanopure or MilliQ quality water ( $18 \mathrm{megohm} \cdot \mathrm{cm}$ or better); Bicinchoninic acid (BCA) Assay Kit was purchased from Pierce (Rockford, IL); Amicon Ultra centrifugal filtration tubes were obtained from Millipore (Bedford, MA) ammonium bicarbonate, ammonium formate, and formic acid were obtained from Fluka (St.Louis, MO); Tris.HCl, urea, thiourea, dithiothreitol (DTT), iodoacetamide, calcium chloride, and trifluoroacetic acid (TFA), were obtained from SigmaAldrich (St.Louis, MO); HPLC-grade methanol (MeOH) and HPLC-grade acetonitrile $\left(\mathrm{CH}_{3} \mathrm{CN}\right.$ ) were purchased from Fisher Scientific (Fair Lawn, NJ); 2,2,2-trifluoroethanol (TFE) was obtained from Aldrich Chemical Company, Inc. (Milwaukee, WI); and sequencing grade modified trypsin was purchased from Promega (Madison, WI). PEDF(SERPINF1)ELISA kit was purchased from Bioproducts MD (Middletown, MD).

\section{Samples}

Forty individual and clinically annotated urine samples were included in the study. We used 10 renal transplant patients, each with biopsy proven acute rejection (AR), as diagnosed by the standardized Banff criteria [17], and 10 renal transplant patients with stable grafts (STA), classified by the absence of any acute rejection or significant chronic injury on a protocol biopsy. All urine samples were collected at the time of a clinically indicated or protocol biopsy, prior to any treatment intensification. Our controls included 10 non-specific proteinuria (NS) patients, from minimal change disease, not currently on any immunosuppression treatment, and 10 age matching healthy children as healthy controls( $\mathrm{HC})$. As some element of proteinuria 
from injury in AR can be seen, the NS patients provided controls for the presence or absence of proteinuria. Patient demographics were matched (Table 1). The samples were collected in between January 2005 and June 2007and were obtained as part of an ongoing IRB approved study at Stanford University. Approval for the conduct of this research was obtained from the Institutional Review boards at Stanford University and Pacific Northwest National Laboratory (PNNL) in accordance with federal regulations.

\section{Urine collection, initial processing and storage}

Second morning void mid-stream urine samples $(50-100 \mathrm{~mL})$ were collected in sterile containers and were centrifuged at $2000 \times \mathrm{g}$ for $20 \mathrm{~min}$ at room temperature within $1 \mathrm{~h}$ ofcollection. The supernatant was separated from the pellet containing any particulate matter including cells and cell debris. The $\mathrm{pH}$ of the supernatant was adjusted to 7.0 and stored at -80 ${ }^{\circ} \mathrm{C}$ until further analysis. Urine osmolality was measured on all samples.

\section{Recovering and quantification of urinary protein}

Urinary proteins were isolated by removing small $\mathrm{MW}$ peptides and other pigments $(<10 \mathrm{kDa})$ by filtering the supernatant through Amicon Ultra centrifugal filtration tubes (Millipore, Bedford, MA). Thetubes were pre-equilibrated with $10 \mathrm{~mL}$ Milli-Q water and centrifuging at $3000 \times \mathrm{g}$ for $10 \mathrm{~min}$ at $10^{\circ} \mathrm{C}$ using swinging bucket rotors. After equilibration, $10 \mathrm{~mL}$ of urine supernatant was centrifuged for $20 \mathrm{~min}$ at $3000 \times \mathrm{g}$ at $10^{\circ} \mathrm{C}$. The filtrate was recoveredand saved for peptidomic analysis. Urine creatinine was measured using Quantichrom ${ }^{\mathrm{TM}}$ Creatinine Assay Kit (DICT-500) (BioAssay Systems, Hayward, CA). The manufacturer's manual was followed for the assay. The retentate was washed twice with $10 \mathrm{~mL}$ of $20 \mathrm{mM}$ Tris- $\mathrm{HCl}(\mathrm{pH}$ 7.5). The final volume of the retentate was brought to $400 \mu \mathrm{L}$ with $20 \mathrm{mM}$ Tris- $\mathrm{HCl}(\mathrm{pH} 7.5$ ) and was quantified by using bicinchoninic acid (BCA) protein assay (Pierce, Rockford, IL). The mean protein to creatinine ratio for AR, STA, HC and NS were $0.22 \pm 0.15,0.14 \pm 0.06$, $0.05 \pm 0.02$, and $0.67 \pm 1.40$ respectively. After the quantification of individual samples, 4 pooled samples for each AR, STA, NS and HC categories were prepared using $200 \mu \mathrm{g}$ from each individual sample in each category.

\section{Urinary proteomesample preparation}

Samples were desalted using Micron Ultracel YM-3 centrifugal filters MWCO 3000 (Millipore, Billerica, MA) prior to the tryptic digestion following the manufacturer's protocol. Protein concentration was verified after buffer exchange using a BCA Protein Assay. A mixture of 3 standard proteins, purchased individually from Sigma-Aldrich (horse apomyoglobin, rabbit glyceraldehyde-3-phosphate dehydrogenase, and bovine ovalbumin), was added for quality control purposes. Proteins were denatured in $50 \mathrm{mM}$ ammonium bicarbonate, $\mathrm{pH} 7.8$, $8 \mathrm{M} \mathrm{Urea} \mathrm{for} 1 \mathrm{~h}$ at $37{ }^{\circ} \mathrm{C}$ and then reduced with $10 \mathrm{mM}$ DTT at $37^{\circ} \mathrm{C}$ for $1 \mathrm{~h}$. After this they were alkylated with $40 \mathrm{mM}$ iodoacetamide at room temperature for $1 \mathrm{~h}$ in the absence of light. Samples were diluted 10 fold with $50 \mathrm{mM}$ ammonium bicarbonate, $\mathrm{pH} 7.8$ and sufficient amount of $1 \mathrm{M}$ calcium chloride was added to the samples to obtain a concentration of $1 \mathrm{mM}$ in the sample. Sequencing grade-modified trypsin was prepared by adding $20 \mu \mathrm{L}$ of $50 \mathrm{mM}$ ammonium bicarbonate, $\mathrm{pH} 7.8$ to a vial containing $20 \mu \mathrm{g}$ trypsin and after $10 \mathrm{~min}$ incubation at $37^{\circ} \mathrm{C}$ was used for digestion of the samples. Tryptic digestion was performed for $3 \mathrm{~h}$ at 37 ${ }^{\circ} \mathrm{C}$ with 1:50 (w/w) trypsin-to-protein ratio. Rapid freezing of the samples in liquid nitrogen quenched the enzymatic digestion.

Digested samples were desalted by using a solid-phase extraction (SPE) C18 column (Discovery DSC-18, SUPELCO, Bellefonte, PA) conditioned with $\mathrm{MeOH}$ and rinsed with 0.1 $\%$ TFA, $1 \mathrm{~mL}$, and washed with $4 \mathrm{~mL}$ of $0.1 \% \mathrm{TFA} / 5 \% \mathrm{CH}_{3} \mathrm{CN}$. Peptides were eluted from the SPE column with $1 \mathrm{~mL}$ of $0.1 \% \mathrm{TFA} / 80 \% \mathrm{CH}_{3} \mathrm{CN}$ and concentrated inaSpeed-Vac SC 250 Express (Thermo Savant, Holbrook, NY) to a volume of $\sim 50-100 \mu \mathrm{L}$. The peptide 
concentration was measured using the BCA Protein Assay. Digested samples were stored at $-80^{\circ} \mathrm{C}$ until needed for analysis or further processing.

\section{Strong cation exchange (SCX) fractionation}

Digested samples (200.0-350.0 $\mu \mathrm{g}$ ) were reconstituted with $900 \mu \mathrm{L}$ of $10 \mathrm{mM}$ ammonium formate, $\mathrm{pH} 3.0 / 25 \% \mathrm{CH}_{3} \mathrm{CN}$ and fractionated by SCX chromatography on a Polysulfoethyl A $2.1 \mathrm{~mm} \times 200 \mathrm{~mm}, 5 \mu \mathrm{M}, 300 \AA$ column with $2.1 \mathrm{~mm} \times 10 \mathrm{~mm}$ guard column (PolyLC, Inc., Columbia, MD) using an Agilent 1100 series HPLC system (Agilent, Palo Alto, CA) The flow rate was $200 \mu \mathrm{L} / \mathrm{min}$, and mobile phases were $10 \mathrm{mM}$ ammonium formate, $\mathrm{pH} 3.0 / 25 \%$ $\mathrm{CH}_{3} \mathrm{CN}$ (A), and $500 \mathrm{mM}$ ammonium formate, $\mathrm{pH} 6.8 / 25 \% \mathrm{CH}_{3} \mathrm{CN}$ (B). After loading 900 $\mu \mathrm{L}$ of sample onto the column, the mobile phase was maintained at $100 \% \mathrm{~A}$ for $10 \mathrm{~min}$. Peptides were then separated using a gradient from 0 to $50 \% \mathrm{~B}$ over $40 \mathrm{~min}$, followed by a gradient of $50-100 \%$ B the following $10 \mathrm{~min}$. The mobile phase was held at $100 \%$ B for $10 \mathrm{~min}$, followed by $\mathrm{H}_{2} \mathrm{O}$ rinsing for the next $20 \mathrm{~min}$ and final re-conditioning with A for $10 \mathrm{~min}$. A total of 60 fractions over 90 min separation were collected for each depleted sample, and each fraction was dried under vacuum in a Speed-Vac. The fractions were dissolved in $25 \mu \mathrm{L}$ of $25 \mathrm{mM}$ ammonium bicarbonate, $\mathrm{pH} 7.8$ and combined into 32 fractions for LC-MS/MS analysis. The first 20 fractions were combined into one and were desalted by C18 SPE column (Discovery DSC-18, SUPELCO, Bellefonte, PA), the next 30 fractions were not pooled and each was analyzed separately, and $5.0 \mu \mathrm{L}$ of each of the last 10 fractions were combined together into fraction number 32. A $5.0 \mu \mathrm{L}$ aliquot of each fraction was analyzed by capillary LC-MS/MS.

\section{Capillary LC-MS/MS analysis}

The HPLC system consisted of a custom configuration of 100-mL Isco Model 100DM syringe pumps (Isco, Inc., Lincoln, NE), 2-position Valco valves (Valco Instruments Co., Houston, TX), and a PAL autosampler (Leap Technologies, Carrboro, NC), allowing for fully automated sample analysis across four separate HPLC columns [18]. Reversed phase capillary HPLC columns were manufactured in-house by slurry packing $3-\mu \mathrm{m}$ Jupiter $\mathrm{C}_{18}$ stationary phase (Phenomenex, Torrence, CA) into a 60-cm length of $360 \mu \mathrm{m}$ o.d. $\times 75 \mu \mathrm{m}$ i.d. fused silica capillary tubing (Polymicro Technologies Inc., Phoenix, AZ) that incorporated a 2.0- $\mu \mathrm{m}$ retaining screen in a 1/16" $75 \mu \mathrm{m}$ i.d. union (Valco Instruments Co., Houston, TX). Mobile phase consisted of $0.2 \%$ acetic acid and $0.05 \%$ TFA in water (A) and $0.1 \%$ TFA in $90 \%$ $\mathrm{CH}_{3} \mathrm{CN} / 10 \%$ water (B). The mobile phase was degassed by using an in-line Degassex Model DG4400 vacuum degasser (Phenomenex, Torrence, CA). The HPLC system was equilibrated at $10 \mathrm{k}$ psi with $100 \%$ mobile phase $\mathrm{A}$, and then a mobile phase selection valve was switched 20 min after injection, which created a near-exponential gradient as mobile phase B displaced A in a $2.5 \mathrm{~mL}$ active mixer. A 30 -cm length of $360 \mu \mathrm{m}$ o.d. $\times 15 \mu \mathrm{m}$ i.d. fused silica tubing was used to split $\sim 20 \mu \mathrm{L} / \mathrm{min}$ of flow before it reached the injection valve ( $5 \mu \mathrm{L}$ sample loop). The split flow controlled the gradient speed under conditions of constant pressure operation (10k psi). Flow ratethrough the capillary HPLC column was $\sim 900 \mathrm{~nL} / \mathrm{min}$. A ThermoScientific LTQ linear ion trap mass spectrometer (ThermoScientific, San Jose, CA) was coupled with the LCsystem using anin-house electrospray ionization (ESI) interface for all sample analysis. Homemade $150 \mu \mathrm{m}$ o.d. $\times 20 \mu \mathrm{m}$ i.d. chemically-etched electrospray emitters were used [19]. The heated capillary temperature and spray voltage were $200^{\circ} \mathrm{C}$ and $2.2 \mathrm{kV}$, respectively. Data was acquired for $90 \mathrm{~min}$, beginning $30 \mathrm{~min}$ after sample injection (10 min into gradient). Full spectra (AGC setting: $3 \times 10^{4}$ ) were collected from $400-2000 \mathrm{~m} / \mathrm{z}$ followed by data-dependent ion trap MS/MS spectra (AGC setting: $1 \times 10^{4}$ ) of the ten most abundant ions applying collision energy of $35 \%$. A dynamic exclusion time of $60 \mathrm{~s}$ was applied. 


\section{Peptide and protein identification using MS/MS spectra}

Peptides were identified from MS/MS spectra by matching them with predicted peptides from the protein FASTA file from the human International Protein Index (IPI -European Bioinformatics Institute) database (version 3.20, released at August 22, 2006) containing 61,225 protein entries using the SEQUEST ${ }^{T M}$ algorithm [20]. A standard parameter file allowing for a dynamic addition of oxidation to the methionine residue and a static (nonvariable) carboxamidomethylation modification to the cysteine residue, with a mass error window of $3 \mathrm{Da}$ units for precursor mass and $1 \mathrm{Da}$ unit for fragmentation mass was used. The searches were allowed for all possible peptide termini, i.e., not limited by tryptic-only termini. Not limiting by tryptic termini means that we did not require the peptide to end in a K, R, or be the termini of the protein. Peptide identifications were considered acceptable if they passed the thresholds determined acceptable for human plasma by Qian et al.[21] and passed an additional filter of a PeptideProphet score of at least 0.7 [22]. The PeptideProphet score is representative of the quality of the SEQUEST ${ }^{T M}$ identification and is based on a combination of XCorr, delCn, $\mathrm{Sp}$, and a parameter that measures the probability that the identification occurred by random chance. Peptide Prophet scores are normalized to a 0 to 1 scale, with 1 being the highest confidence value.

\section{Protein grouping}

Due to the high redundancy of peptide-to-protein relationships inherent in the IPI database, two protein grouping programs were used to consolidate sequence identifications. ProteinProphet [23]uses the identified peptide sequences to weight the probability that the peptide originated from a particular protein. When parent protein distinctions cannot be determined, those proteins are grouped together and assigned an index value. The second method of grouping proteins involved aligning whole-protein sequences and assigning similarity scores based on the amino acid composition. This method utilized the BLAST algorithm to determine similarity of each protein to all other proteins in the input file. Then these similarities are clustered into groups of like similarities using a Perl script.

\section{Differentially expressed proteins}

Protein-level spectral counts were obtained by summing peptide-level spectral counts. To quantitatively compare relative protein abundances between different pools of samples, we considered either presence or absence of a particular protein in different phenotypes. For the proteins that were identified in multiple categories we used a cutoff criteria of $\geq 2$ of fold change in log base(2) of spectral count with at least 5 spectral counts in one of the phenotypes being compared.

\section{ELISA assays for Tamm-Horsfall protein (UMOD)}

A total of 60 urine samples (20 AR, 20 STA and $20 \mathrm{HC}$ ) were included. Urine samples were diluted 200 foldin PBS buffer. Aliquots of diluted $100 \mu \mathrm{L}$ of urine was incubated in ReactiBind 96-Well Plates over night at $4{ }^{\circ} \mathrm{C}$. The plate was washed 5 times with $1 \times$ PBS buffer containing $0.05 \%$ Tween 20 . The wells were then blocked by $100 \mu \mathrm{L}$ of $25 \%$ FCS in PBS to prevent non-specific binding of the antibody. The wells were then incubated with 1:3000 fold diluted anti-Tamm Horsfall Glycoprotein PAB at room temperature for $1 \mathrm{hr}$. The color was developed by using turbo-TMB (Pierce Inc, Rockford, IL) and stopped bythe addition of 100 $\mu \mathrm{L}$ of $2 \mathrm{M} \mathrm{H}_{2} \mathrm{SO}_{4}$ and the plate was read byaSPECTRAMax 190 microplate reader (Molecular Devices, Sunnyvale, CA).

\section{ELISA for Pigment Epithelium-Derived Factor-PEDF(SERPINF1), and CD44}

Sandwich ELISA assays were performed to validate the observed elevated levelsof PEDF (SERPINF1)and CD44 in urine collected from an independent set of patients and controls 
which included AR ( $\mathrm{n}=20)$, STA ( $\mathrm{n}=20)$, NS [ $\mathrm{n}=8$ for PEDF(SERPINF1) and 6 for CD44], $\mathrm{HC}(\mathrm{n}=6)$.

\section{PEDF(SERPINF1)ELISA}

An ELISA kit for Pigment Epithelium-Derived factor (PEDF)or SERPINF1 (BioProducts, MD) was used for the purpose and the reagents were prepared following the manufacturer's manual. Briefly, after an initial optimizing step for optimal dilution of urine, the urine samples were diluted (1:40) in Assay Diluent. The ELISA plate with $100 \mu \mathrm{L}$ of standards and the diluted urine specimens was incubated at $37^{\circ} \mathrm{C}$ for $1 \mathrm{~h}$. After the incubation the plates were washed 5 times with Plate Wash Buffer. The wells were incubated with $100 \mu$ L PEDF (SERPINF1) detector antibody at $37^{\circ} \mathrm{C}$ for $1 \mathrm{~h}$ and washed 5 times with the wash buffer. This step was followed by incubation of the wells with $100 \mu \mathrm{L}$ Streptavidin Peroxidase Working solution.

\section{CD44 ELISA}

An ELISA kit for CD44(ABCam Inc, Cambridge, MA) was used for the purpose and the reagents were prepared following the manufacturer's manual. Briefly, after an initial optimizing step for the optimal dilution of urine, the urine samples were diluted (1:1) in Standard Diluent Buffer. The ELISA plate with $100 \mu \mathrm{L}$ of standards and the diluted urine specimenswas incubated at room temperature for $1 \mathrm{~h}$. After the incubation the plates were washed 5 times with washing solution. The plate was incubated for $30 \mathrm{~min}$ with $50 \mu \mathrm{L}$ of diluted biotinylated anti-CD44 in all wells. The plate was washed 5 times with the wash solution and was incubated with $100 \mu \mathrm{L}$ HRP solution in all the wells for $30 \mathrm{~min}$. This step was followed by a wash step.

All the assays were developed by ready-to-use TMB substrate followed by addition of Stop Solution. All the plates were read by a SPECTRAMax 190 microplate reader (Molecular Devices, Sunnyvale, CA). Protein concentrations were determined from a standard curve generated from the standards obtained with the kit.

\section{Correlation analysis between the spectral counts and the quantity observed from ELISA assay}

We obtained quantitative data for UMOD, pigment epithelial derived factor (PEDF) (SERPINF1), and CD44 using ELISA assays on an independent set of patients. The quantitative data obtained from ELISA was compared with the spectral count data for each protein observed in the discovery phase using the LC-MS/MS platform. P Values and Pearson correlation coefficients were calculated using SAS $®$ program(SAS Corporate Statistics, Cary, NC). The ROC was calculated by logistic regression model for 3 proteins based on the values of AR vs.no-AR that included STA, HC and NS.

\section{Enrichment analysis and pathway impact analysis}

The enrichment analysis for identified proteins was performed using Ingenuity Pathway Analysis (http://www.ingenuity.com). A list of all human genes was used as reference for computing significance, which was obtained from the Onto-Tools database [24]. The pathway analysis was also performed using Pathway-Express [25-26]. Pathway-Express performs a novel impact analysis on signaling pathways, which in addition to the number of proteins in IPA, considers important biological factors such as the topology of the pathway, position of the protein on the pathway, amount of change in protein expression, and the type of interaction between the protein in each pathway. 


\section{Results}

\section{Detection of novel urinary proteins expands the urinary proteome database}

We identified 1446 urinary proteins by using LC-MS/MS-based shotgun proteomics on urine from renal patients and healthy individuals. A minimum of 2 unique, non-redundant peptides per protein to be identified was the criteria for positive protein identification. The false discovery rate (FDR) for protein identifications is $\sim 0.1 \%$ based on target-decoyanalysis using Sequest, while the FDR at the unique peptide level is $\sim 3.0 \%$. The number of total proteins identified in this study with a 1 peptide identified per protein criteria was 3296 . The complete list of proteins is provided as supplemental data (Supplemental Table 1). We identified 1001, 1159,1325 , and 1340 proteins respectively in AR, NS, STA, and HC urine, respectively (Figure 1). We used Ingenuity Pathway Analysis -IPA (Ingenuity ${ }^{\circledR}$ Systems, Redwood City, CAwww.ingenuity.com) on predicted proteins based on the human genome database [27] and mapped the proteins identified with previously annotated urinary proteins and proteins of renal origin. A total of 756 urinary proteins from our 1446 protein list have been listed as urinary proteins (UP). Thisleaves 690 proteins in our list of urinary proteins as novel and werelabeled as novel urinary proteins (NUP) (Supplemental Table 2). We compared the list of urinary proteins identified from healthy individuals in this study with 1543 identified by Adachi et al. [12] and 1160 by Gonzales et al [13](Figure 2A). This study has added 560 new proteins tothe existing urinary proteome observed in healthy subjects.

\section{Urinary proteins are enriched with extracellular proteins, complement and coagulation, glycan structures - degradation, cell adhesion, and ECM-receptor interaction}

Gene ontological classification [28]sub-grouped the 1446 identified proteins into 5 major groups; 279 were cytoplasmic proteins, 325 were extracellular proteins, 28 were nuclear proteins, 304 were plasma membrane, and 108 had as yet unknown sub-cellular localization. We found that extracellular and plasmamembrane proteins were enriched, and nuclear proteins were relatively underrepresented in the urine proteome when compared with the predicted human proteome from the human genome database. This is in agreement with previously published data [27]. Hypergeometric analysis revealed that the enrichment of proteins of extracellular origin $(p<1.00 \mathrm{E}-6)$ and plasma membrane in urine $(p<3.00 \mathrm{E}-6)$ is highly significant compared to the human proteome. The major representing pathways were complement and coagulation cascades $(P=1.95 \mathrm{E}-12)$, glycan structures - degradation $(P=1.31 \mathrm{E}-11)$, cell adhesion molecules (CAMs) $(P=1.77 \mathrm{E}-11)$, ECM-receptor interaction ( $P=1.87 \mathrm{E}-11)$, cell communication $(P=2.04 \mathrm{E}-11)$, focal adhesion $(P=2.62 \mathrm{E}-11)$, axonguidance $(P=2.86 \mathrm{E}-11)$, regulation of actin cytoskeleton $(P=4.97 \mathrm{E}-09)$, cytokine-cytokine receptor interaction $(P=3.26 \mathrm{E}-09)$, and hematopoietic cell lineage $(P=4.89 \mathrm{E}-08)$.

\section{There was no specific bias towards plasma and renal proteins in the urine of renal patients and depletion of ECM-receptors and integrins in renal patients}

We identified the 1420 proteins that were detected in the urine of patients with normal renal function (HC and STA), and only 1206 proteins were found in patients with active renal dysfunction (AR and NS). There was no bias of the health status of the kidney in terms of known urinary, blood, and renal proteins when we used Ingenuity Pathway Analysis® based annotation. Among the total 1420 proteins identified in HC and STA; 578, 463, and 434 proteins were previously known urinary, blood and renal proteins; while in the total 1206 proteins identifiedin AR and NS; 504, 405, and 353 proteins were previously known urinary, blood, and renal proteins (Table 2).

67 proteins were uniquely identified only in healthy urine (HC) (Supplemental Table 3). EHdomain-containing protein 1 (EDH1) and creatinine kinase B-type (CKB) were the two most abundant proteins identified in this group. Among these proteins a significant number of 
proteins are known to be involved in cell morphology (CEACAM6, CR1, CRYAB, ERK, GNA12, GNA13, GNAQ, KDR, NOS3, PAFAH1B1, PP1CB, PTPRF, RAB4A, RYR2), metabolic disease and lipid metabolism(ACO1, CD7, DDC, EHD1, EXTL2, FAM125A, FLRT3, LPHN3, MAN2A2, PPIC, RAB4B, RAB5B, SORD, VPS28, and VPS37D).

\section{Correlation between data obtained based on spectral count and ELISA assays}

Therelative abundance of identified urinary proteins was measured by protein-level spectral counts adopting a weighted fold-change statistic, and assigning increased weight for the more frequently observed proteins. Observed abundances of highly abundant proteins are less likely to be biased in a particular direction due to random variations in the peptide detection from sample to sample. The higher the abundance of the proteins involved, the more confident we are that the observed fold-change difference is close to the actual fold-change difference. A complete dataset of identified proteins and observed spectral counts for each protein for all the phenotypes tested is provided in (Supplemental Table 4). UMOD, SERPINF1 (PEDF), and CD44 proteins were analyzed by ELISA assay to obtain concentrations for the proteins. The spectral counts for the proteins measured by LC-MS were compared and correlated to the concentration calculated from ELISA assays on an independent set of the urine samples from similar phenotypes that were used in the discovery phase (Table 2). We observed a good correlation in between the spectral counts and quantitative data measured from ELISA assays. An ELISA assay was run for urinary Tamm-Horsfall protein. It was performed on an independent validation set of samples with AR $(n=20)$, STA $(n=20)$, and HC $(n=20)$. The mean UMOD concentration in AR urine $(5.50 \pm 0.85 \mu \mathrm{g} / \mathrm{mL})$ stable graft urine $(13.95 \pm 2.94 \mu \mathrm{g} / \mathrm{mL})$, and healthy normal control urine $(19.80 \pm 2.71 \mu \mathrm{g} / \mathrm{mL})$ has been compared with the spectral counts for AR (122), STA (363), and healthy control (567) with a correlation coefficient of 0.99 and P-value 0.02. The mean PEDF(SERPINF1)concentration in AR urine $(0.370 \pm 0.350$ $\mathrm{ng} / \mathrm{mL})$, STA urine $(0.006 \pm 0.009 \mathrm{ng} / \mathrm{mL}$, and HCurine $(0.01 \pm 0.009 \mathrm{ng} / \mathrm{mL})$ was compared with the spectral counts for AR (75), STA (54), and healthy control (15) with a correlation coefficient of 0.78 .

When we assayed CD44 in an independent sample set of urine samples, we measured a mean CD44 concentration in AR urine $(1.67 \pm 1.17 \mathrm{ng} / \mathrm{mL})$, STA urine $(2.81 \pm 1.10 \mathrm{ng} / \mathrm{mL}$, and HC urine $(2.54 \pm 1.41 \mathrm{ng} / \mathrm{mL})$. This was in good correlation with spectral counts observed from LCMS experiments for AR urine (15), STA (42), and healthy controls (126) with a correlation coefficient of 0.59. When we combined total concentration measured from ELISA assay and compared to the spectral counts for corresponding samples, there was an excellent correlation $\left(\mathrm{R}^{2}=0.84\right)$ with a $P$-value $<0.0012$ (Table 2$)$.

\section{Urinary proteins specific to Nephrotic Syndrome (NS)}

We analyzed the urine from patients with nonspecific proteinuria. Nine proteins were uniquely identified in the NS urine, which included proteins like keratin 5b (KRT78), Isoform DPI of desmoplakin (DESP), Protein-glutamine gamma-glutamyltransferase 4 (TGM4), secretogranin-3 (SCG3), Periplakin (PPL), collagen type V alpha 1 (COL5A1), and cell growth regulator with EF hand domain 1 (CGREF1) (Supplemental Table 5). We also identified 20 proteins present in both $\mathrm{HC}$ and NS that were altogether absent from the renal transplant patients (Supplemental Table 6). The proteins that were either only present in NS urine or upregulated in NS urine were involved in the acute phase response signaling $(P=4.53 \mathrm{E}-21)$, the coagulation system $(P=2.17 \mathrm{E}-11)$, and the complement system $(P=1.63 \mathrm{E}-02)$.

\section{Differential expression of proteins in acute rejection (AR)}

We analyzed the relative abundance of proteins which were identified in both renal transplant patients with AR episode and those with stable graft (STA). There were 9 proteins that were identified only in AR urine, but not in urine of HC, STA, and NS phenotypes. These included 
HLA class II histocompatibility antigen, DP(W4) beta chain (HLA-DBP), HLA class II histocompatibility antigen, DRB1-8 beta chain (IgHM), C4b-binding protein alpha chain (C4BPA), MHC class II antigen (HLA-DR), Myosin light chain 1 (MYL6B), HLA class II histocompatibility antigen DQ(3) beta chain (HLA-DQB1) (Table 4A). In addition a total of 68 proteins that were absent in AR, but present in HC, STA, and NS categories, included Isoform 1 of Melanotransferrin (MFI2), Isoform 1 of FRAS1-related extracellular matrix protein 2 (FREM2), Isoform 2 of FRAS1-related extracellular matrix protein 2 (ROR1), Isoform 2 of Neural cell adhesion molecule L1-like protein (PLD3), Golgi apparatus protein 1 (CRYL1), and Thyrotropin-releasing hormone-degrading ectoenzyme (TRHDE) (Table 4B). For a more rigorous quantitative analysis of proteinsthat were identified in AR and STA, we used spectral counts observed for each protein. Protein-level spectral counts were obtained by summing up peptide-level spectral counts. A total of 284 proteins were observed to be either up-regulated or down-regulated in the AR urine when compared to the patients with stable graft with a cut-off criteria of $\geq 2$ of fold change in terms of log base(2) of spectral counts (Supplemental Table 7). The list of 23 up-regulated proteins included ceruloplasmin (CP), complement C5 (C5), hemoglobin subunit alpha (HBA1), prostate-specific antigen(PSA), complement $\mathrm{C} 2(\mathrm{C} 2)$, etc. and are listed in Table 5A. The proteins in this group were associated mainly with acute phase response signaling $(P=3.77 \mathrm{E}-08)$ and complement system $(\mathrm{P}=5.46 \mathrm{E}-07)$. The top 23 down-regulated proteins out of 261 included $\alpha$-1-microglobulin (AMBP), cubulin (CUBN), Tamm-Horsfall protein (UMOD), amylase, alpha (AMY2A), fibrilin1 (FBN1), and Collagen type XII, alpha1 (COL12A1)proteins and are listed in Table 5B. From their spectral count evaluationsall 9 identified collagens, COL5A3, COL4A2, COL1A2, COL27, COL1A1, COL15A1, COL6A1, COL12A1 were decreased in AR urine including type IV collagenase (MMP-9) and its inhibitor TIMP-1. A number of SERPIN family members SERPING, SERPINB12, SERPINB3, and SERPINB4 were decreased in AR urine; whereas, two members SERPINC1 and SERPINF1 (PEDF) were increased. The downregulated proteins were found to be involved in ECM-receptor interaction, cell communication, and Glycan structure degradation (all with $P \leq 0.0005$ ). We used up-regulated proteins in AR to generate a heat map (Figure 3), which demonstrate some of the injury mechanisms in AR.

\section{Verification of AR associated proteins Tamm-Horsfall protein (UMOD), Pigment Epithelium- Derived Factor (SERPINF1), and CD44}

We performed an ELISA assay on UMOD, PEDF(SERPINF1), and CD44 as AR specific novel urinary proteins for verification. We verified the decreased UMOD in AR patients. An ELISA assay was run for urinary UMOD, and was performed on an independent validation set of samples with AR $(n=20), \operatorname{STA}(n=20)$, and HC $(n=20)$. The mean UMOD concentration in AR urine $(5.50 \pm 0.85 \mu \mathrm{g} / \mathrm{mL})$ was significantly lower than the stable graft urine $(13.95 \pm 2.94 \mu \mathrm{g} /$ $\mathrm{mL}(P<0.01)$ and the healthy normal control urine $(19.80 \pm 2.71 \mu \mathrm{g} / \mathrm{mL})(P<0.001)$ (Figure 4A). In another experiment we observed an elevated concentration of PEDF(SERPINF1)in the AR urine compared to the urine collected from the urine from patients with stable graft function and other controls that included healthy normal control and non-specific proteinuric patients. The mean PEDF(SERPINF1)concentration in AR urine $(0.0 .396 \pm 0.0 .344 \mu \mathrm{g} / \mathrm{mL})$ was significantly higher than STA urine $(0.006 \pm 0.009 \mu \mathrm{g} / \mathrm{mL}(P=0.0001)$, NS urine $(0.019$ $\pm 0.038 \mu \mathrm{g} / \mathrm{mL})(P=0.005)$, and $\mathrm{HC}$ urine $(0.01 \pm 0.009 \mu \mathrm{g} / \mathrm{mL})(P=0.005)$ (Figure 4B). When we assayed CD44 in an independent sample set of individual urine samples, we observed a decreased concentration of CD44 in the AR urine compared to the urine collected from stable graft function and other controls that included the healthy normals and non-specific proteinuric patients. The mean CD44 concentration in AR urine $(1.67 \pm 1.17 \mathrm{ng} / \mathrm{mL})$ was significantly lower than STA urine $(2.81 \pm 1.10 \mathrm{ng} / \mathrm{mL}(P=0.0001)$, NS urine $(1.83 \pm 1.63 \mathrm{ng} / \mathrm{mL})(P=0.005)$, and the HCurine $(2.54 \pm 1.41 \mathrm{ng} / \mathrm{mL})(P=0.005)$ (Figure $4 \mathrm{C})$. The ROC analysis was performed by the logistic regression model for the three proteins based on the values of AR vs. no-AR including STA,HC, and NS. The area under the curve for AR classification ofCD44 is $97.3 \%$ 
with $\mathrm{p}=0.0058$, PEDF is $93.2 \%$ with $\mathrm{p}=0.0205$ and UMOD is $84.6 \%$ with $\mathrm{p}=0.0005$

(Supplemental Figure 1).

\section{Discussion}

This study describes the application of shotgun proteomics to expand the existing healthy normal urinary proteome database and its use in the identification and the verification of 3 potential biomarkers specific for AR in renal transplantation. Urine is the most relevant biofluid in biomarker discovery efforts for kidney diseases. Thus the analysis of its proteomeis very relevant [29-30]. Mass spectrometry-based proteomics provides a fast and accurate means of obtaining protein identification from complex samples and allows for rapid screening for disease markers [31]. Renal transplantation has remained the optimal treatment for patients with end-stage kidney disease [14]. Even though improvement in the short term survival of grafts has been reported, AR of renal transplant still remains the primary risk factor for graft functional decline, chronic rejection and graft loss [32-35]. Therefore, AR specific biomarkers are important for patient and allograft surveillance. Herein, we used LC-MS based proteomics to investigate urine from kidney transplant patients. Using this approach, we have discovered the potential protein biomarker candidates that could provide a way to diagnose acute rejection of renal transplant effectivelyand non-invasively. For this discovery step, using pediatric and young adult patient samples, we applied a pooling approach to minimize individual and disease heterogeneity.

Different proteomics approaches have been applied to analyze the urinary proteome in the past, which has helped to build up the list of urinary proteins identified to date [7-10,12-13]. Early studies used gel-based techniques to identify a relatively smaller number of proteins; whereas use of gel-free LC-MS has proven to be an efficient way to identify a greater number of proteins. Adachi et al. identified 1492 proteins using the urine collected from the healthy individuals [12]. In a recent report Gonzales et al. have identified 1160 from human urinary exosomes [13](summarized in Figure 2). In this report we have identified a new set of urinary proteins with a stringent criteria of a minimum of two unique, non-redundant peptidesper protein with $\sim 0.1 \%$ FDR for protein identification. As summarized in Figure 2 there is a significant overlap among the list of proteins identified by Adachi et al. [36] and Gonzales et al. [13]. Yet there are new proteins identified in each study, which will eventually help to build a comprehensive human urinary proteome database. Apart from contributing to the existing urinary protein database, we have analyzed urinary proteins identified from the healthy normal controls to those with nephrotic syndrome and renal transplantation which yielded specific proteins related to renal injury associated with nephrotic syndrome as well as renal transplantation that included $\mathrm{AR}$ and stable graft function.

One of the challenges of translational research is that there is such a wide range (approximately as high as 10 orders of magnitude) of protein concentrations present in the bio-specimen, especiallyin blood and urine. The experimental design applied in this study has provided us with protein identifications for high abundance proteins such as UMOD with a concentration measured at 5 orders of magnitude $(\sim 0.07 \mathrm{mg} / \mathrm{mL})$. This is more than the concentration measured for protein $\mathrm{S} 100$ calcium binding A4 protein $(\sim 2 \mathrm{ng} / \mathrm{mL})$ in urine. In this study we calculated spectral counts as a semi-quantitative means for comparison and a weighted foldchange was used to derive a list of potential biomarker proteins. We tested three proteins whose concentrations differed by 4 orders magnitude, whereas there was a nearly perfect correlation to a good correlation for the proteins ranging from mean spectral counts 9 to $360\left(\mathrm{r}^{2}=0.59-\right.$ 0.99 ). The data suggest that the label-free LC-MS/MS spectral count data provides a relatively good quantification for high abundance to moderate abundance proteins. If the spectral count is low, it has a poor correlation with the real concentration in the sample and may require a more stringent labeling methods such aseitheriTRAQ [37] or the ${ }^{18} \mathrm{O} /{ }^{16} \mathrm{O}$ labeling method 
[38]to achieve more accurate quantification. In this study, we used spectral counts as our measure of relative abundance to list potential AR specific proteins.

Given the scope of the study, we took three relevant protein candidates to verify their validity as being AR specific as discovered by the label-free approach using LC-MS/MS. Since the ELISA assay is known to be robust, sensitive for performing quantitative measurements of proteins in a simple setting unlike MRM. We performed the ELISA assay on THP (UMOD), PEDF(SERPINF1), and CD44 as AR specific novel urinary proteins. We have demonstrated that the reduced levels of THP (UMOD)and CD44 and the elevated level of PEDF(SERPINF1) in AR urine could be verified as both a highly specific and sensitive method to detect AR within the transplanted kidney, regardless of the confounding effect of proteinuria, immunosuppression, age or gender.

The Tamm-Horsfall Protein (also known as uromodulin -UMOD) is localized in the epithelial cells of the thick ascending limbs of Henle's loop and the most proximal part of the distal convoluted tubule[39]. This protein is suggested to be involved in the constitutive inhibition of calcium crystallization [40]. Mutation of the UMOD gene has been linked to familial juvenile hyperuricemic nephropathy (FJHN) as well as autosomal-dominant medullary cystic kidney disease (MCKD2) in children[41]. Ithas also been reported to be involved in prevention of urinary tract infection[42]. This protein has intrigued nephrologists for a long time because of its high abundance in healthy urine with no obvious role [39]. Kaden et al. observed reduced urinary UMOD delayed onset of transplanted function and increased urinary UMOD with the recovery of kidney health[43]. However, the use of UMOD as a diagnostic parameter was not recommended. Sejdieu et al. have recently related decreased UMOD in urine to the development of renal failure and cardiovascular death within 20 years in type1, but not in type 2 diabetes [44]. Our observation of the reduced level of Tamm-Horsfall protein in AR does agree with the pattern of low urinary UMOD in naturally occurring peptides that is seen in acute rejection and chronic allograft rejection and may need to be further validated with a larger cohort of patient samples[30,45].

Pigment epithelium-derived factor precursor (PEDF) is also known as serpin peptidase inhibitor. Clade F (SERPINF1) is a member of serine protease inhibitors and is known to be apotent inhibitor of angiogenesis in the eye [46]. PEDF(SERPINF1)was detected as one of the proteins whose level was elevated in the AR urine. PEDF(SERPINF1)is one of the major inhibitors of angiogenesis and is involved in physiological activities including wound healing, ischemia reperfusion injury and cancer metastasis to name a fewexamples. No direct correlation has been established for PEDF(SERPINF1)in renal injury. In a recent report Matsuyama et al. observed an increased PEDF(SERPINF1)level in the serum of diabetic patients with both diabetic retinopathy and nephropathy and suggested this could be a reflection of microvascular damage[47]. Our observation of the increased level of PEDF(SERPINF1)in AR urine could provide a new way to monitor the health status of renal transplant. It would take further investigation to understand the underlying mechanism related to its involvement in AR.

CD44 is a cell-surface glycoprotein known to be involved in cell-cell interactions, cell adhesion and migration [48]. It acts as a receptor for hyaluronic acid (HA), osteopontin, collagens, and matrix metalloproteinases (MMPs) [49]. A number of activities for this protein have been reported. These include lymphocyte activation, recirculation and homing, hematopoiesis, and tumor metastasis. Transcripts for this gene undergo a complex alternative splicing that results in many functionally distinct isoforms; however, the full length nature of some of these variants has not yet been determined. 
High throughput genomicsor proteomics studies generate not only a list of disease specific genes/proteins, but also help in understanding the underlying molecular pathways and events. Their biological activity and their association to different pathways provides a better understanding of the acute rejection event which is generally known to be mediated by $\mathrm{T}$ cell responses to antigens from the donor organs which are different than the ones in the recipient. This study has provided a broad view of underlying events in the kidney at the time of acute rejection. We observed up-regulation of MHC proteins which are involved in the presentation of foreign antigens to Tcells. This observation is along the same trend from the observed role of increased abundance of MHC class II antibodies in previous reports[50-51]. By impact analysis on signaling pathways, we identified a number of AR specific urinary proteins that are part of the acute phase response, complement and coagulation cascades. On the other hand, there is a significant down-regulation of proteins involved with ECM, cytoarchitecture in AR urine when compared to STA and healthy controls. This suggestsa significant turnover of extracellular matrix during an AR episode.

\section{Conclusion}

In summary, for the first time, we have demonstrated that shotgun proteomics is a viable way to discover potential biomarkers in transplantation. The outcome of this study demonstrates that comparative analysis strategy using pooled samples is a simple and effective way to achieve a list of potential biomarkers that can track with normal and disease states. Crossvalidation of selected results from these studies, by an economically viable and convenient ELISA assay withan independent set of urine samples, demonstrates the feasibility of the translation of this approach to clinical practice. In conclusion, this label-free, semi-quantitative approach to analyze the urinary proteome in normal and disease states provides a robust and sensitive method for detection of urinary proteins for serial, non-invasive clinical monitoring for graft rejection after kidney transplantation. Since this study included pediatric and young adult patients as study subjects, a similar study on adult renal transplant patients will contribute in finding biomarkers that are more effective. In order to further validate the effectiveness of this approach in identifying AR specific marker proteins, a longitudinal response analysis on prospectively collected urine samples from a larger independent cohort of patients is warranted.

\section{Supplementary Material}

Refer to Web version on PubMed Central for supplementary material.

\section{Acknowledgments}

The authors thank the NIH (grant RR018522 to R.D.S.) for support of portions of this research and the Environmental Molecular Sciences Laboratory (EMSL) for use of the instrumentation applied in this research. EMSL is a U.S. Department of Energy (DOE)national scientific user facility located at PNNL in Richland, Washington. PNNL is a multi-program national laboratory operated by Battelle Memorial Institute for the DOE under Contract DEAC05-76RL01830. We thank Ms. Amery Chen, Dr Li Li and Dr. PurveshKhatri, and the other members of the Sarwal lab for their help in the manuscript preparationand Dr Frank Golich for critically reading the manuscript.

\section{List of abbreviations}

$\begin{array}{ll}\text { AR } & \text { Acute rejection } \\ \text { STA } & \text { Stable graft function } \\ \text { NS } & \text { Nonspecific proteinuria } \\ \text { HC } & \text { healthy normal control } \\ \text { BCA } & \text { Bicinchoninic acid }\end{array}$


PEDF Pigment Epithelium-Derived factor

\section{References}

1. Cravatt BF, Simon GM, Yates JR 3rd. The biological impact of mass-spectrometry-based proteomics. Nature 2007;450(7172):991-1000. [PubMed: 18075578]

2. de Hoog CL, Mann M. Proteomics. Annu Rev Genomics Hum Genet 2004;5:267-93. [PubMed: 15485350]

3. Veenstra TD, et al. Biomarkers: mining the biofluid proteome. Mol Cell Proteomics 2005;4(4):409_ 18. [PubMed: 15684407]

4. Laronga C, Drake RR. Proteomic approach to breast cancer. Cancer Control 2007;14(4):360-8. [PubMed: 17914336]

5. Hu S, Loo JA, Wong DT. Human body fluid proteome analysis. Proteomics 2006;6(23):6326-53. [PubMed: 17083142]

6. Jacobs JM, et al. Utilizing human blood plasma for proteomic biomarker discovery. J Proteome Res 2005;4(4):1073-85. [PubMed: 16083256]

7. Wang L, et al. Concanavalin A-captured glycoproteins in healthy human urine. Mol Cell Proteomics 2006;5(3):560-2. [PubMed: 16316981]

8. Pisitkun T, Shen RF, Knepper MA. Identification and proteomic profiling of exosomes in human urine. Proc Natl Acad Sci U S A 2004;101(36):13368-73. [PubMed: 15326289]

9. Sun W, et al. Human urine proteome analysis by three separation approaches. Proteomics 2005;5(18): 4994-5001. [PubMed: 16281181]

10. Pieper R, et al. Characterization of the human urinary proteome: a method for high-resolution display of urinary proteins on two-dimensional electrophoresis gels with a yield of nearly 1400 distinct protein spots. Proteomics 2004;4(4):1159-74. [PubMed: 15048996]

11. Chen YT, et al. Large-scale protein identification of human urine proteome by multidimensional LC and MS/MS. Proteomics Clin Appl 2007;1:577-587.

12. Adachi $\mathrm{J}$, et al. The human urinary proteome contains more than 1500 proteins, including a large proportion of membrane proteins. Genome Biol 2006;7(9):R80. [PubMed: 16948836]

13. Gonzales PA, et al. Large-Scale Proteomics and Phosphoproteomics of Urinary Exosomes. J Am Soc Nephrol. 2008

14. Groothoff JW. Long-term outcomes of children with end-stage renal disease. Pediatr Nephrol 2005;20 (7):849-53. [PubMed: 15834618]

15. Reichelt $\mathrm{O}$, et al. Prediction of renal allograft rejection by urinary protein analysis using ProteinChip Arrays (surface-enhanced laser desorption/ionization time-of-flight mass spectrometry). Urology 2006;67(3):472-5. [PubMed: 16527560]

16. Gonzalez-Buitrago JM, Ferreira L, Lorenzo I. Urinary proteomics. Clin Chim Acta 2007;375(1-2): 49-56. [PubMed: 16942764]

17. Racusen LC. The Banff schema and differential diagnosis of allograft dysfunction. Transplant Proc 2004;36(3):753-4. [PubMed: 15110651]

18. Livesay EA, et al. Fully automated four-column capillary LC-MS system for maximizing throughput in proteomic analyses. Anal Chem 2008;80(1):294-302. [PubMed: 18044960]

19. Kelly RT, et al. Chemically etched open tubular and monolithic emitters for nanoelectrospray ionization mass spectrometry. Anal Chem 2006;78(22):7796-801. [PubMed: 17105173]

20. Eng JK, McCormack L, Yates JR. An approach to correlate tandem mass spectral data of peptides with amino acid sequences in protein database. J Am Soc Mass Spectrom 1994;5(11):976-989.

21. Qian WJ, et al. Quantitative proteome analysis of human plasma following in vivo lipopolysaccharide administration using 16O/18O labeling and the accurate mass and time tag approach. Mol Cell Proteomics 2005;4(5):700-9. [PubMed: 15753121]

22. Keller A, et al. Empirical statistical model to estimate the accuracy of peptide identifications made by MS/MS and database search. Anal Chem 2002;74(20):5383-92. [PubMed: 12403597] 
23. Nesvizhskii AI, et al. A statistical model for identifying proteins by tandem mass spectrometry. Anal Chem 2003;75(17):4646-58. [PubMed: 14632076]

24. Draghici S, Sellamuthu S, Khatri P. Babel's tower revisited: a universal resource for cross-referencing across annotation databases. Bioinformatics 2006;22(23):2934-9. [PubMed: 17068090]

25. Tarca AL, et al. A novel signaling pathway impact analysis. Bioinformatics 2009;25(1):75-82. [PubMed: 18990722]

26. Draghici S, et al. A systems biology approach for pathway level analysis. Genome Res 2007;17(10): 1537-45. [PubMed: 17785539]

27. Lander ES, et al. Initial sequencing and analysis of the human genome. Nature 2001;409(6822):860921. [PubMed: 11237011]

28. Ashburner M, et al. Gene ontology: tool for the unification of biology. The Gene Ontology Consortium. Nat Genet 2000;25(1):25-9. [PubMed: 10802651]

29. Sigdel TK, et al. Optimizing protein recovery for urinary proteomics, a tool to monitor renal transplantation. Clin Transplant 2008;22(5):617-623. [PubMed: 18459997]

30. Sigdel TK, et al. Urinary peptidomic analysis identifies potential biomarkers for acute rejection of renal. Clin Proteom 2009;5(2):103-113.

31. Qian WJ, et al. Advances and challenges in liquid chromatography-mass spectrometry-based proteomics profiling for clinical applications. Mol Cell Proteomics 2006;5(10):1727-44. [PubMed: 16887931]

32. Sarwal MM, et al. Promising early outcomes with a novel, complete steroid avoidance immunosuppression protocol in pediatric renal transplantation. Transplantation 2001;72(1):13-21. [PubMed: 11468528]

33. Corey HE, et al. Renal allograft rejection in children and young adults: the Banff classification. Pediatr Nephrol 1995;9(3):309-12. [PubMed: 7543274]

34. Gulanikar AC, et al. The incidence and impact of early rejection episodes on graft outcome in recipients of first cadaver kidney transplants. Transplantation 1992;53(2):323-8. [PubMed: 1738926]

35. Hariharan S, et al. Improved graft survival after renal transplantation in the United States, 1988 to 1996. N Engl J Med 2000;342(9):605-12. [PubMed: 10699159]

36. Adachi J, et al. The human urinary proteome contains more than 1500 proteins including a large proportion of membranes proteins. Genome Biol 2006;7(9):R80. [PubMed: 16948836]

37. Ross PL, et al. Multiplexed Protein Quantitation in Saccharomyces cerevisiae Using Amine-reactive Isobaric Tagging Reagents. Mol Cell Proteomics 2004;3(12):1154-1169. [PubMed: 15385600]

38. Mirgorodskaya OA, et al. Quantitation of peptides and proteins by matrix-assisted laser desorption/ ionization mass spectrometry using (18)O-labeled internal standards. Rapid Commun Mass Spectrom 2000;14(14):1226-32. [PubMed: 10918372]

39. Kokot F, Dulawa J. Tamm-Horsfall protein updated. Nephron 2000;85(2):97-102. [PubMed: 10867513]

40. Schlieper G, et al. Inhibitors of calcification in blood and urine. Semin Dial 2007;20(2):113-21. [PubMed: 17374084]

41. Hart TC, et al. Mutations of the UMOD gene are responsible for medullary cystic kidney disease 2 and familial juvenile hyperuricaemic nephropathy. J Med Genet 2002;39(12):882-92. [PubMed: 12471200]

42. Weichhart $\mathrm{T}$, et al. Current concepts of molecular defence mechanisms operative during urinary tract infection. Eur J Clin Invest 2008;38(Suppl 2):29-38. [PubMed: 18826479]

43. Kaden J, et al. Urinary Tamm-Horsfall protein as a marker of renal transplant function. Urol Res 1994;22(3):131-6. [PubMed: 7992456]

44. Sejdiu I, Torffvit O. Decreased urinary concentration of Tamm-Horsfall protein is associated with development of renal failure and cardiovascular death within 20 years in type 1 but not in type 2 diabetic patients. Scand J Urol Nephrol 2008;42(2):168-74. [PubMed: 17907053]

45. Quintana LF, et al. Application of label-free quantitative peptidomics for the identification of urinary biomarkers of kidney chronic allograft dysfunction. Mol Cell Proteomics 2009;8(7):1658-73. [PubMed: 19357086] 
46. Dawson DW, et al. Pigment epithelium-derived factor: a potent inhibitor of angiogenesis. Science 1999;285(5425):245-8. [PubMed: 10398599]

47. Matsuyama K, et al. Relationship between pigment epithelium-derived factor (PEDF) and renal function in patients with diabetic retinopathy. Mol Vis 2008;14:992-6. [PubMed: 18523656]

48. Ponta H, Sherman L, Herrlich PA. CD44: from adhesion molecules to signalling regulators. Nat Rev Mol Cell Biol 2003;4(1):33-45. [PubMed: 12511867]

49. Goodison S, Urquidi V, Tarin D. CD44 cell adhesion molecules. Mol Pathol 1999;52(4):189-96. [PubMed: 10694938]

50. Campos EF, et al. Post-transplant anti-HLA class II antibodies as risk factor for late kidney allograft failure. Am J Transplant 2006;6(10):2316-20. [PubMed: 16925566]

51. Langan LL, et al. Post-transplant HLA class II antibodies and high soluble CD30 levels are independently associated with poor kidney graft survival. Am J Transplant 2007;7(4):847-56. [PubMed: 17391128] 


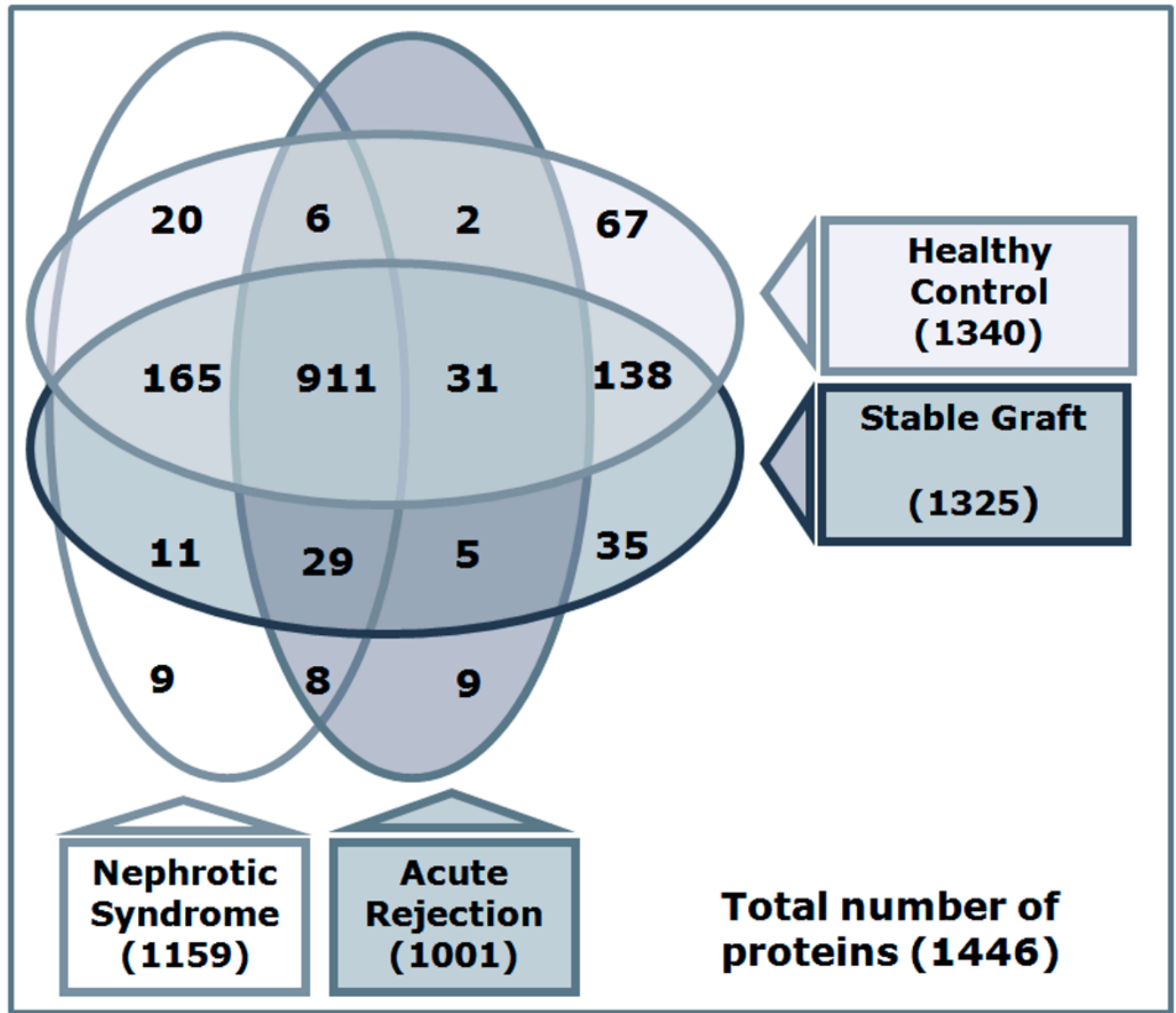

Figure 1. Urinary proteins were identified from urine collected from healthy as well as renal patients with or without kidney transplant

Number of proteins identified in urine collected from renal transplant patients with biopsy proven acute rejection (AR), renal transplant patients with stable graft function (STA), healthy control (HC), and renal patients with nephrotic syndrome (NS). 

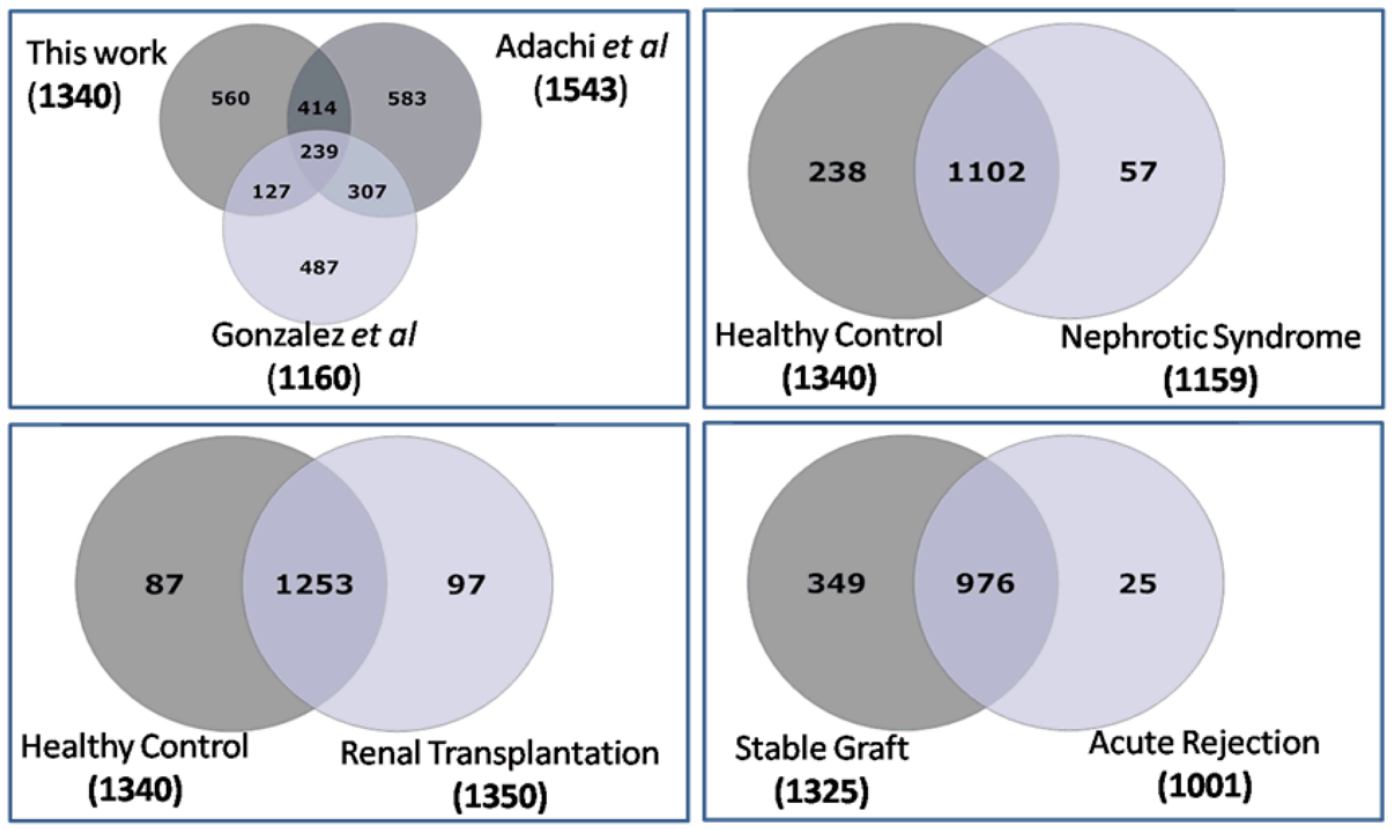

Figure 2.

Urinary proteins identified from different patients groups including the healthy controls (HC) were compared. [A] A Venn diagram to compare urinary proteins from healthy normal individuals identified in this study to the proteins identified by Adachi et al ${ }^{12}$ and urinary proteins identified by ${ }^{38}$. [B] A comparison of proteins identified in healthy urine (HC) and urine of nephrotic syndrome (NS). [C] A comparison of proteins identified in healthy urine (HC) and urine of renal transplant patients both stable graft (STA) and acute rejection (AR) combined. [D] A comparison of proteins identified in urine from stable graft (STA) to urine of acute rejection (AR). 


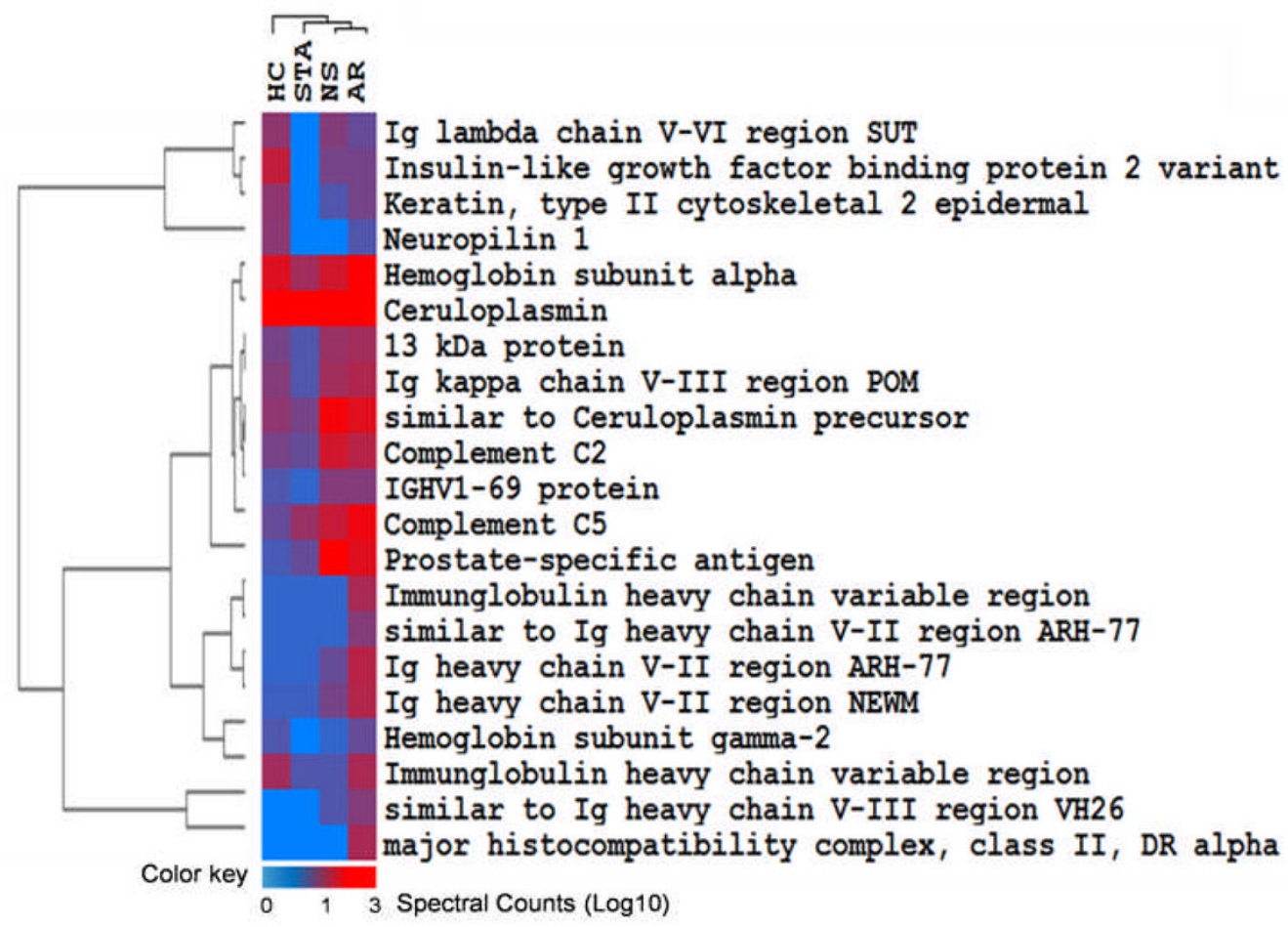

Figure 3.

A heat map demonstrating level of elevated proteins in AR compared to STA when compared to healthy urine and NS. 


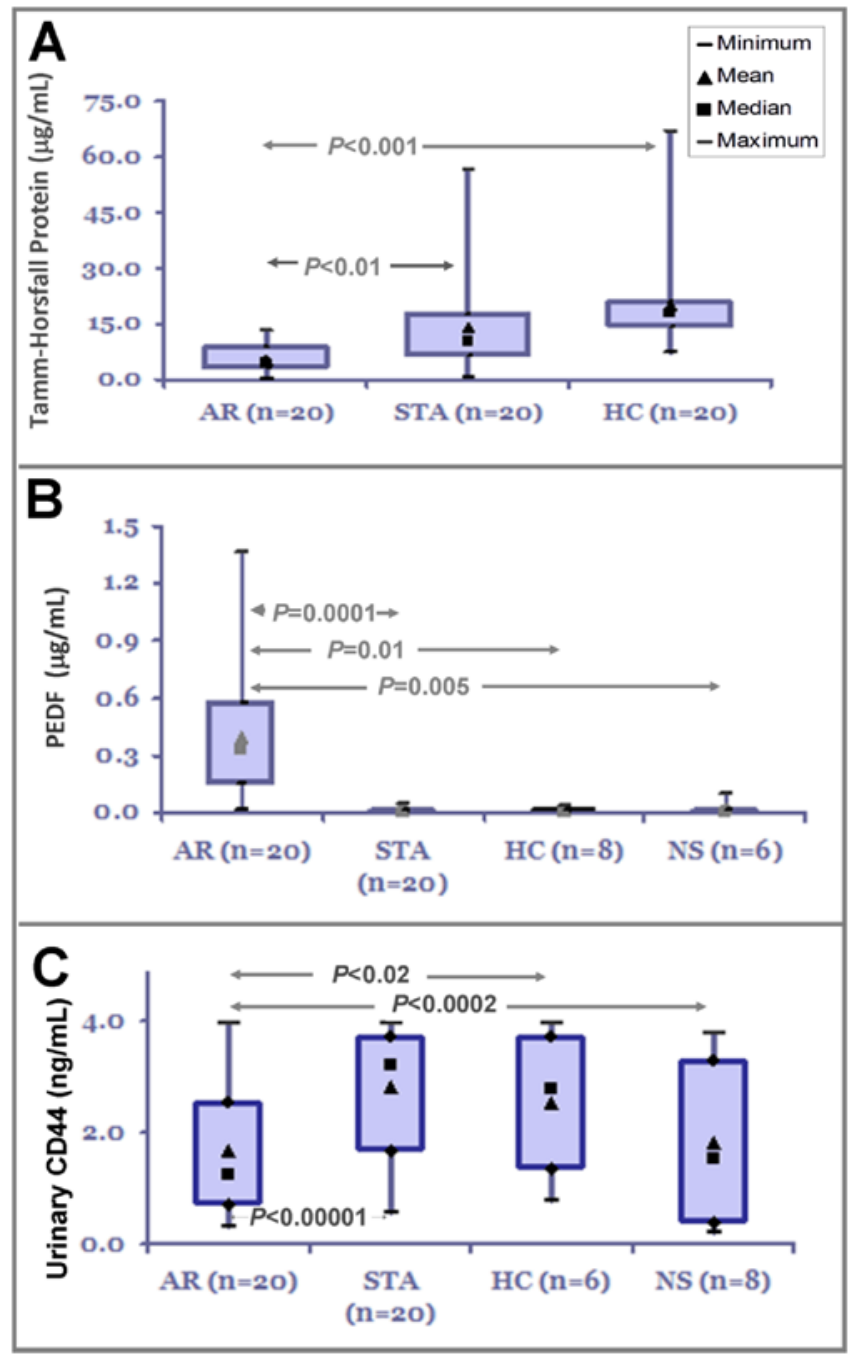

Figure 4. Verification of discovery of potential biomarker candidates by ELISA assay Urinary protein level of three candidate proteins, THP, PEDF (SERPINF1), and CD44 were measured by ELISA using an independent set of samples from different phenotypes. (A) A decreased level of THP was observed in AR urine ( $\mathrm{n}=20$, mean concentration $5.50 \mu \mathrm{g} / \mathrm{mL})$ when compared to STA urine $(\mathrm{n}=20$, mean concentration $13.95 \mu \mathrm{g} / \mathrm{mL})$ with $\mathrm{P}<0.01$ and healthy control urine $(\mathrm{n}=20$, mean concentration $19.80 \mu \mathrm{g} / \mathrm{mL})$ with $\mathrm{P}<0.001$. (B) An increased level of PEDF protein was observed in AR urine $(\mathrm{n}=20$, mean concentration $0.40 \mu \mathrm{g} / \mathrm{mL})$ when compared to STA urine $(\mathrm{n}=20$, mean concentration $0.01 \mu \mathrm{g} / \mathrm{mL})$ with $\mathrm{P}=0.0001$, with healthy control urine $(\mathrm{n}=8$, mean concentration $0.01 \mu \mathrm{g} / \mathrm{mL})$ with $\mathrm{P}=0.02$, and with nephrotic syndrome urine $(\mathrm{n}=6$, mean concentration $0.02 \mu \mathrm{g} / \mathrm{mL})$ with $\mathrm{P}=0.005$. (C) A decreased level of CD44 protein was observed in AR urine $(n=20$, mean concentration $1.67 \mathrm{ng} / \mathrm{mL})$ when compared to STA urine $(\mathrm{n}=20$, mean concentration $12.57 \mathrm{ng} / \mathrm{mL})$ with $\mathrm{P}<0.00001$, with healthy control urine $(\mathrm{n}=6$, mean concentration $11.76 \mathrm{ng} / \mathrm{mL})$ with $\mathrm{P}<0.02$, and with nephrotic syndrome urine ( $\mathrm{n}=6$, mean concentration $8.54 \mathrm{ng} / \mathrm{mL}$ ) with $\mathrm{P}<0.0002$. The boxes in the box plots are bounded by $75^{\text {th }}$ and $25^{\text {th }}$ percentiles of the data and the whiskers extend to the minimum and maximum values. As there are no statistically significant differences in urine osmolality between the samples groups (data not shown), the differences in concentration between groups are unlikely to be in part due to differences in water excretion, variably diluting or concentrating the markers. 


\section{Table 1}

\section{Patient demographic information}

Patient information on 60 renal transplant patients (30 AR, 30 STA).

\begin{tabular}{|c|c|c|c|}
\hline & Acute Rejection (AR) $(n=30)$ & Stable Graft Function $($ STA) $(n=30)$ & $P$ value \\
\hline Mean Age & $12 \pm 5$ & $14 \pm 5$ & 0.21 \\
\hline Age Range & $3-19$ & $6-21$ & \\
\hline Immunosuppression, $\% \mathrm{SF}^{\#}$ & $66 \%$ & $50 \%$ & 0.19 \\
\hline Race $^{*}$ & $63 \%, 13 \%, 0 \%, 17 \%, 7 \%$ & $59 \%, 7 \%, 10 \%, 17 \%, 7 \%$ & 0.45 \\
\hline Donor, $\%$ living donor & $40 \%$ & $53 \%$ & 0.44 \\
\hline Mean GFR $\left(\mathrm{mL} / \mathrm{min} / 1.73 \mathrm{~m}^{2}\right)$ & $87.45 \pm 38.46$ & $124 \pm 29.86$ & 0.0001 \\
\hline
\end{tabular}

${ }^{\#}$ SF: Steroid-free immunosuppression treatment, consisting of daclizumab induction + mycophenolate mofetil + tacrolimus

* Race: 1=Caucasian; 2= Hispanic; 3=Asian; 4=African American; 5=Other 


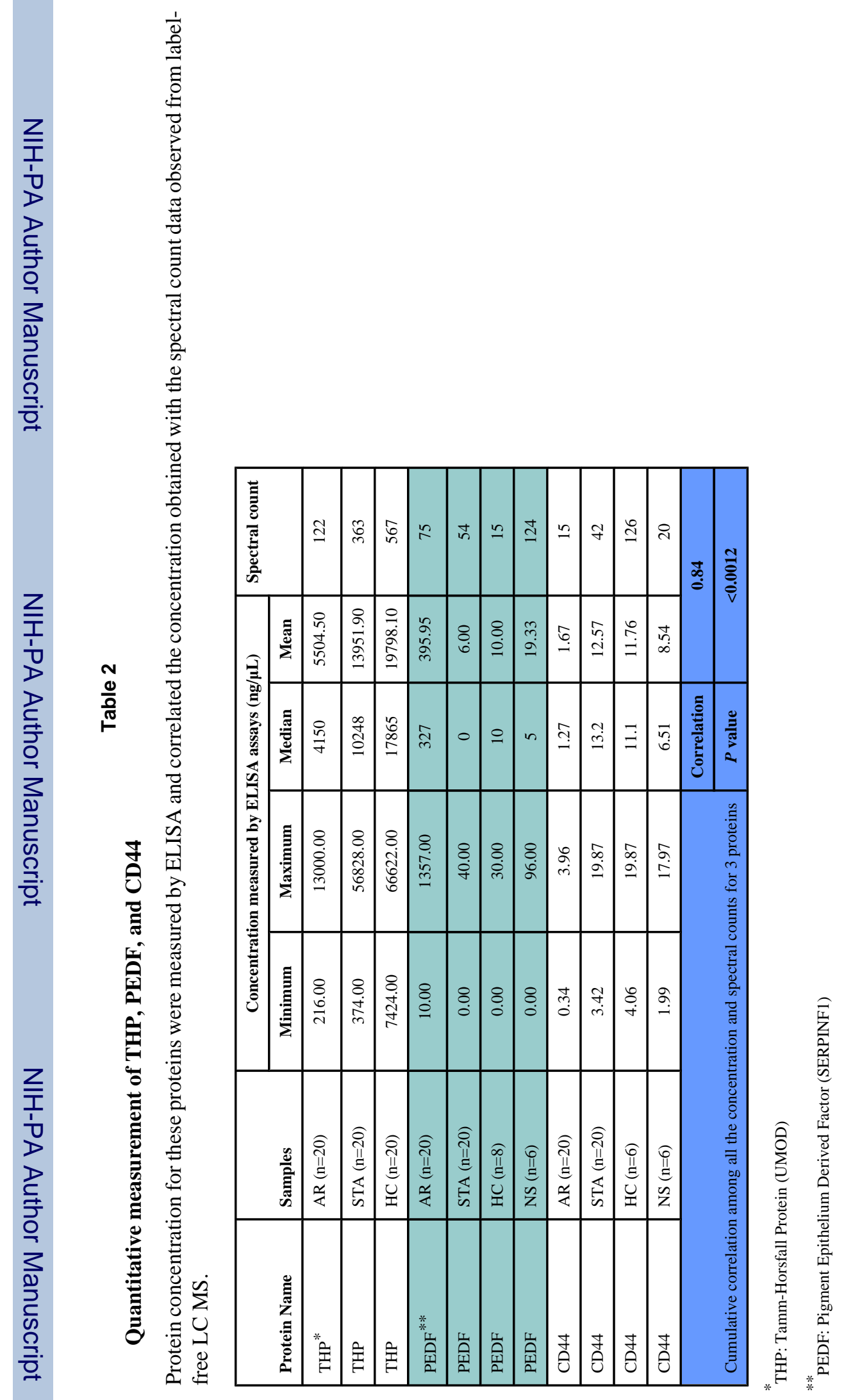


Table 3

No bias of plasma or renal proteins in renal patients.

\begin{tabular}{|l|c|c|}
\hline & Proteins identified in AR and NS combined & Proteins identified in HC and STA combined \\
\hline Proteins identified in this study & $(1206)$ & $(1420)$ \\
\hline Previously known urinary proteins & 504 & 578 \\
\hline Previously known plasma/serum proteins & 405 & 463 \\
\hline Previously known kidney proteins & 353 & 434 \\
\hline
\end{tabular}




\section{Table 4}

Proteins specific to acute rejection.

\begin{tabular}{|l|l|l|l|}
\hline \multicolumn{4}{|l|}{ Table 4A: List of proteins identified only in AR urine } \\
\hline S. No. & IPI ID & Gene Symbol & Protein Name \\
\hline 1 & IPI00103082.7 & HLA-DBP & HLA class II histocompatibility antigen, DP(W4) beta chain \\
\hline 2 & IPI00005180.2 & IgHM & HLA class II histocompatibility antigen, DRB1-8 beta chain \\
\hline 3 & IPI00021727.1 & C4BPA & C4b-binding protein alpha chain \\
\hline 4 & IPI00641889.1 & KIAA1522 & 25 kDa protein \\
\hline 5 & IPI00746396.1 & & 302 kDa protein \\
\hline 6 & IPI00760688.2 & HLA-DR & MHC class II antigen (Fragment) \\
\hline 7 & IPI00027255.1 & $M Y L 6 B$ & Myosin light chain 1, slow-twitch muscle A isoform \\
\hline 8 & IPI00783351.1 & SUMF2 & sulfatase modifying factor 2 isoform d \\
\hline 9 & IPI00743218.1 & HLA-DQB1 & HLA class II histocompatibility antigen, DQ(3) beta chain \\
\hline
\end{tabular}

\begin{tabular}{|c|c|c|c|}
\hline S. No & IPI ID & Gene Symbol & Protein Name \\
\hline 1 & IPI00029275.1 & MFI2 & Isoform 1 of Melanotransferrin \\
\hline 2 & IPI00180707.8 & FREM2 & Isoform 1 of FRAS1-related extracellular matrix protein 2 \\
\hline 3 & IPI00644416.1 & RORI & Isoform 2 of FRAS1-related extracellular matrix protein 2 \\
\hline 4 & IPI00328243.1 & PLD3 & Isoform 2 of Neural cell adhesion molecule L1-like protein \\
\hline 5 & IPI00645031.1 & CRYL1 & Golgi apparatus protein 1 \\
\hline 6 & IPI00007798.1 & TRHDE & Thyrotropin-releasing hormone-degrading ectoenzyme \\
\hline 7 & IPI00556267.1 & GPC1 & FAT tumor suppressor homolog 4 \\
\hline 8 & IPI00218795.1 & SELL & Isoform 2 of Melanotransferrin \\
\hline 9 & IPI00156171.2 & ENPP2 & Isoform 1 of Ectonucleotide pyrophosphatase/phosphodiesterase 2 \\
\hline 10 & IPI00641153.2 & $G L G 1$ & Glypican 1 variant (Fragment) \\
\hline 11 & IPI00007244.1 & MPO & Isoform H17 of Myeloperoxidase \\
\hline 12 & IPI00604773.1 & PODXL & Target of Nesh-SH3 (Tarsh) (Nesh binding protein) (NeshBP) \\
\hline 13 & IPI00010790.1 & $B G N$ & Biglycan \\
\hline 14 & IPI00064262.1 & DCHS1 & Protocadherin-16 \\
\hline 15 & IPI00641672.1 & CD320 & Isoform 3 of Crumbs homolog 2 \\
\hline 16 & IPI00019907.1 & GPC3 & Glypican-3 \\
\hline 17 & IPI00025240.1 & $\mathrm{CDH16}$ & Isoform 1 of Cadherin- 16 \\
\hline 18 & IPI00182728.2 & $V P S 4 B$ & Vacuolar sorting protein $4 \mathrm{~b}$ \\
\hline 19 & IPI00413016.3 & CADM2 & CDNA FLJ35635 fis, clone SPLEN2011805 \\
\hline 20 & IPI00413781.3 & CXCL12 & Vacuolar sorting protein $4 \mathrm{a}$ \\
\hline 21 & IPI00419215.3 & $A 2 M L 1$ & Hypothetical protein DKFZp761G128 \\
\hline 22 & IPI00385751.3 & FUCA1 & Delta-notch-like EGF repeat-containing transmembrane \\
\hline 23 & IPI00025512.2 & $H S P B 1$ & Heat-shock protein beta- 1 \\
\hline 24 & IPI00165360.4 & $M P S T$ & 3-mercaptopyruvate sulfurtransferase \\
\hline
\end{tabular}




\begin{tabular}{|c|c|c|c|}
\hline S. No & IPI ID & Gene Symbol & Protein Name \\
\hline 25 & IPI00017672.4 & $N P$ & Hypothetical protein FLJ25678 \\
\hline 26 & IPI00103175.1 & CANT1 & Isoform 1 of Soluble calcium-activated nucleotidase 1 \\
\hline 27 & IPI00217253.2 & GCHFR & GTP cyclohydrolase 1 feedback regulatory protein \\
\hline 28 & IPI00645085.2 & LOC653163 & Intrinsic factor-vitamin B12 receptor \\
\hline 29 & IPI00646907.1 & $S L C 12 A 3$ & ROR1 protein \\
\hline 30 & IPI00011564.1 & $S D C 4$ & Syndecan-4 \\
\hline 31 & IPI00023014.1 & $V W F$ & von Willebrand factor \\
\hline 32 & IPI00024012.4 & FZD7 & Frizzled-7 \\
\hline 33 & IPI00027769.1 & ELA2 & Leukocyte elastase \\
\hline 34 & IPI00333140.7 & DNER & Phospholipase D3, isoform 1 \\
\hline 35 & IPI00009294.1 & CRIMI & Cysteine-rich motor neuron 1 protein \\
\hline 36 & IPI00017160.3 & VTAl & Protein C6orf55 \\
\hline 37 & IPI00027510.1 & $I L 2 R B$ & Interleukin-2 receptor beta chain \\
\hline 38 & IPI00719786.1 & $C D 248$ & Lambda-crystallin \\
\hline 39 & IPI00759832.1 & $Y W H A B$ & PREDICTED: similar to Von Ebners gland protein \\
\hline 40 & IPI00157414.3 & ENPP6 & Ectonucleotide pyrophosphatase/phosphodiesterase 6 \\
\hline 41 & IPI00220253.1 & FGFR3 & Erythrocyte band 7 integral membrane protein \\
\hline 42 & IPI00291737.1 & ITLN1 & Xaa-Pro dipeptidase \\
\hline 43 & IPI00296922.3 & $L A M B 2$ & Intelectin-1 \\
\hline 44 & IPI00004946.8 & CXCL16 & chemokine (C-X-C motif) ligand 16 \\
\hline 45 & IPI00024896.2 & $P B L D$ & Probable isomerase MAWBP \\
\hline 46 & IPI00030887.1 & TYRO3 & Tyrosine-protein kinase receptor TYRO3 \\
\hline 47 & IPI00299059.5 & CHL1 & Tumor-associated calcium signal transducer 2 \\
\hline 48 & IPI00607804.1 & $C R B 2$ & Thioredoxin \\
\hline 49 & IPI00002441.1 & $S D C 1$ & Syndecan-1 \\
\hline 50 & IPI00005517.1 & EFNA5 & Ephrin-A5 \\
\hline 51 & IPI00008554.1 & $A N G$ & Angiogenin \\
\hline 52 & IPI00016027.3 & $F Z D 2$ & Frizzled-2 \\
\hline 53 & IPI00021812.1 & AHNAK & Neuroblast differentiation-associated protein AHNAK (Fragment) \\
\hline 54 & IPI00025252.1 & PDIA3 & Protein disulfide-isomerase A3 \\
\hline 55 & IPI00158145.4 & LILRA5 & leukocyte immunoglobulin-like receptor subfamily A member 5 isoform 1 \\
\hline 56 & IPI00297910.1 & TACSTD2 & Laminin beta- 2 chain \\
\hline 57 & IPI00411356.5 & VPS4A & stomatin isoform b \\
\hline 58 & IPI00440824.2 & $A B I 3 B P$ & chemokine(C-X-C motif) ligand 12 (stromal cell-derived factor 1 ) isoform gamma \\
\hline 59 & IPI00552768.1 & $T X N$ & CDNA FLJ41598 fis, clone CTONG2025496 \\
\hline 60 & IPI00646217.2 & ILIORB & $24 \mathrm{kDa}$ protein \\
\hline 61 & IPI00000861.1 & LASP1 & Isoform 1 of LIM and SH3 domain protein 1 \\
\hline 62 & IPI00006601.5 & $C H G B$ & Secretogranin-1 \\
\hline 63 & IPI00021034.1 & COLAA1 & Collagen alpha-1(IV) chain \\
\hline
\end{tabular}




\begin{tabular}{|l|l|l|l|}
\hline \multicolumn{4}{|c|}{ Table 4B. List of proteins identified in all other phenotypes (STA, HS, and NS) but were not identified in AR urine. } \\
\hline S. No & IPI ID & Gene Symbol & Protein Name \\
\hline 64 & IPI00219682.5 & STOM & L-selectin \\
\hline 65 & IPI00413641.6 & AKR1B1 & CDNA FLJ35595 fis, clone SPLEN2008007 \\
\hline 66 & IPI00257882.6 & PEPD & Isoform 2 of Fibroblast growth factor receptor 3 \\
\hline 67 & IPI00419327.2 & FAT4 & Aldose reductase \\
\hline 68 & IPI00641203.1 & CUBN & podocalyxin-like isoform 1 \\
\hline
\end{tabular}




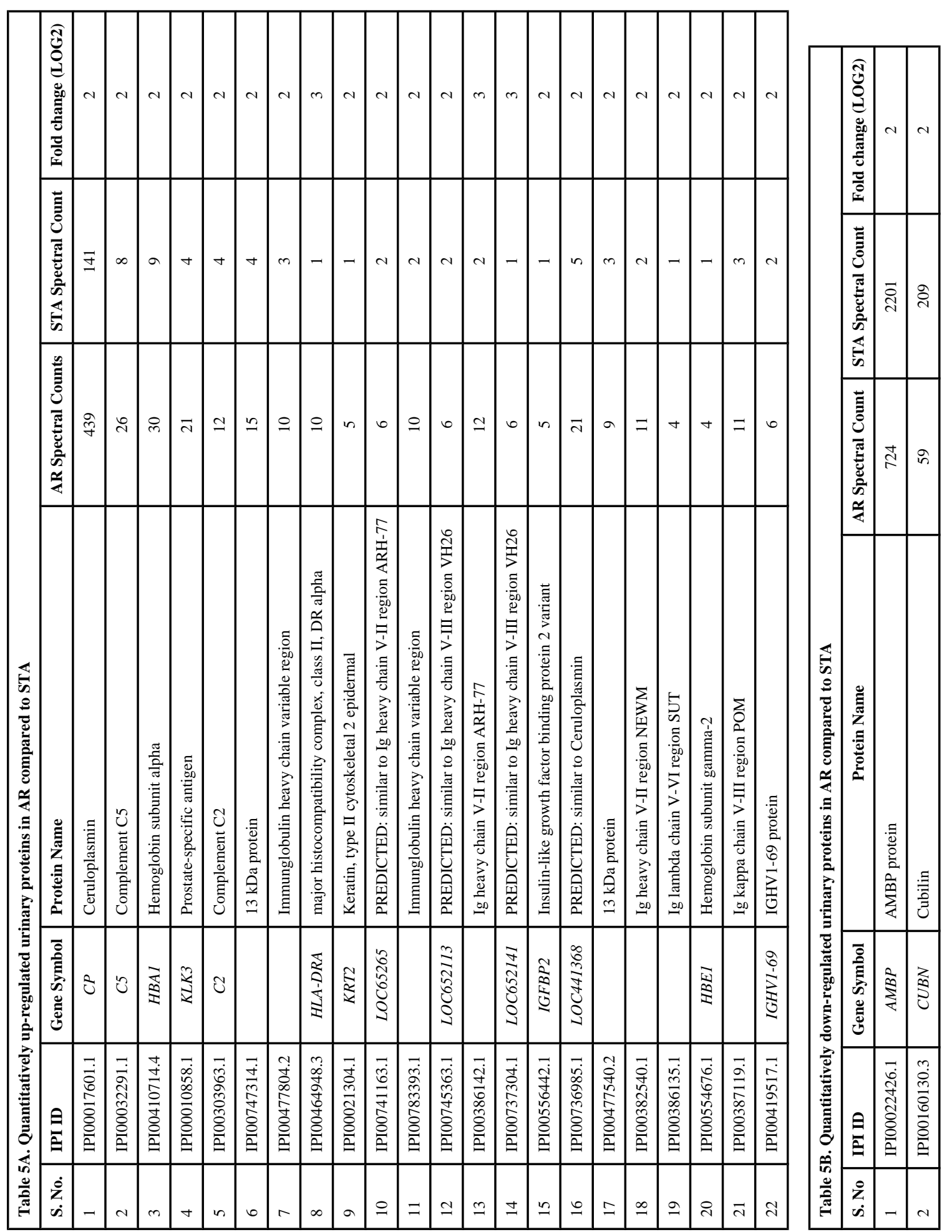




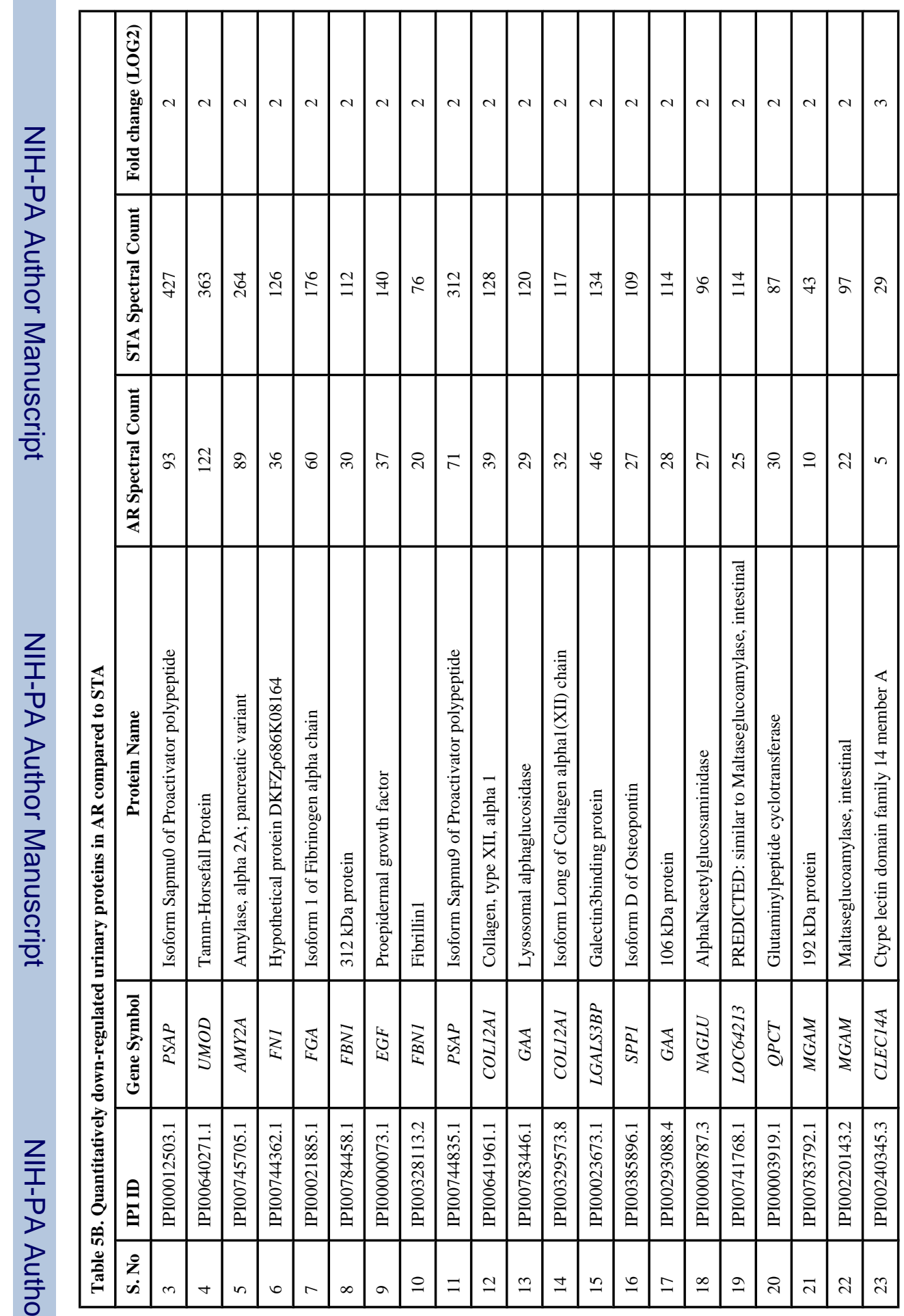

